\title{
Forcing Technology: The Clean Air Act Experience
}

The Supreme Court's 1976 decision in Union Electric Co. v. EPA $A^{1}$ held that states have the authority under the Clean Air Amendments of $1970^{2}$ to require stationary sources of air pollution to comply with regulatory standards or shut down, even if the state's emission control requirements are economically or technically impossible to achieve. The Court found that Congress intended the Amendments to induce rapid improvements in air pollution control technology, to be, in other words, "technology-forcing." 3 This approach to innovation has been criticized, however, as unrealistic and unsuccessful. ${ }^{4}$

1. 427 U.S. 246 (1976).

2. Pub. L. No. 91-604, 84 Stat. 1676 (1970) (current version at 42 U.S.C.A. $\$ \$ 7401-7626$ (West Supp. 1978)). The Clean Air Act was extensively amended in 1977, Pub. L. No. 95.95, 91 Stat. 686 (1977); Pub. L. No. 95-190, 91 Stat. 1399 (1977) (technical amendments). In this Note, sections of the current version of the Act, 42 U.S.C.A. $\$ \$ 7401-7626$ (West Supp. 1978), will be cited without cross-reference.

3. 427 U.S. at 257. The term "technology-forcing" first appeared in cases and commentaries in 1975. See, e.g., Train v. Natural Resources Defense Council, 421 U.S. 60, 91 (1975); Bonine, The Evolution of "Technology-Forcing" in the Clean Air Act, ENVIR. REP. (BNA), Monograph No. 21, 1975.

The Court held in Union Electric that a state implementation plan (SIP) required by $\$ 110$ of the Act could not be rejected "on the ground that it is economically or technologically infeasible." 427 U.S. at 265-66.

This ruling resolved a sharp division among the circuits over the treatment of claims of economic and technological infeasibility. Compare Union Electric Co. v. EPA, 515 F.2d 206 (8th Cir. 1975), aff'd, 427 U.S. 246 (1976) and Indiana \& Mich. Elec. Co. v. EPA, 509 F.2d 839 (7th Cir. 1975) (economic and technological infeasibility irrelevant to state plan approval) with St. Joe Minerals Corp. v. EPA, 508 F.2d 743 (3d Cir. 1975), vacated as moot, 425 U.S. 987 (1976) and Buckeye Power, Inc. v. EPA, 481 F.2d 162, 168-69 (6th Cir. 1973) (feasibility must be considered in state plan approval). But see Bunker Hill Co. v. EPA, 572 F.2d 1286, 1294 (9th Cir. 1977) (9th Circuit ignores Union Electric; requires EPA to show SIP emission limitation "is economically and technologically feasible").

State implementation plans are the Act's primary mechanism for achieving compliance with (1) National Ambient Air Quality Standards (NAAQSs) set by the Environmental Protection Agency (EPA) under $\$ 109,42$ U.S.C.A. $\$ 7409$ (West Supp. 1978); (2) the standards set by the states under $\$ 116,42$ U.S.C.A. $\$ 7416$ (West Supp. 1978); and (3) the requirements contained in $\S 101$ and $\$ \S 160-69,42$ U.S.C.A. $\$ \S 7401,7470-79$ (West Supp. 1978). The overall statutory structure was intended to force control technology innovation to the level necessary to meet national air quality standards. Union Electric Co. v. EPA, 427 U.S. 246, 257 (1976); Train v. Natural Resources Defense Council, 421 U.S. 60, 91 (1975).

4. See, e.g., Union Electric Co. v. EPA, 427 U.S. 246, 269-72 (1976) (Powell, J., concurring) (questioning wisdom of policy that would close electric powerplants for noncompliance); Ayres, Enforcement of Air Pollution Controls on Stationary Sources Under the Clean Air Amendments of 1970, 4 EcoLocY L.Q. 441, $444-45$ (1975); La Pierre, Technology-Forcing and Federal Environmental Protection Statutes, 62 IowA L. Rev. 771, 790.93 (1977). 
This Note evaluates the technical and financial responses of the copper smelting and electric power industries to the Clean Air Act and establishes that technology-forcing works. The evaluation also shows, however, that the Act creates obstacles to continued emissioncontrol innovation. Without such innovation, severe air pollution damage will continue to occur despite compliance with the present type of technology-forcing standards. The Note concludes that Congress should amend the Act, and that the Environmental Protection Agency (EPA) should interpret existing authority, to require continued private emission-control innovation, at a cost that approximates the cost of continued air pollution damage.

\section{Technology-Forcing Doctrine}

In 1970, Congress enacted comprehensive legislation that forced private emission control innovation; this aim was controversial because it assumed that legal commands would induce technical innovation. Responding to difficulties in the 1970 Act, Congress amended the legislation in 1977.

\section{A. The Clean Air Amendments of 1970}

Congress enacted the Clean Air Amendments of 1970 because earlier state and federal air pollution control efforts had failed. ${ }^{5}$ The primitive state of control technology ${ }^{\mathfrak{b}}$ and the low level of funding for private control-technology research, development, and demonstration ${ }^{7}$ were

5. See J. Esposito, Vanishing Air (1970); General Accounting Office, Assessment of Federal and State Enforcement Efforts to Control Air Pollution from Stationary Sources (1973). Harmful emissions increased sharply between 1940 and 1970, particularly during the 1960s. See Office of AIr Quality Planning and Standards, EPA AP-115, Nationwide Air Pollutant Emission Trends, 1940-1970 (1973) [hereinafter cited as EMission TRENDS].

In addition to their stationary source provisions, the 1970 Amendments attempted to hasten automotive emission-control innovation by requiring cars produced in or after 1975 to emit only $10 \%$ of the air pollution produced by 1970 automobiles. Clean Air Act, $\S 202(\mathrm{~b})(\mathrm{l})(\mathrm{A}), 84$ Stat. 1690 (1970) (current version at 42 U.S.C.A. $\S 7521(\mathrm{~b})(\mathrm{l})(\mathrm{A})$ (West Supp. 1978)).

6. See, e.g., S. Rep. No. 1196, 91st Cong., 2d Sess. 9 (1970), reprinted in Senate Coma. on Public Works, A Legislative History of the Clean Air Amendments of 1970, S. Doc. No. 18, 93d Cong., 2d Sess., at 409 (1974) ("Air pollution control requires a new and unique technology." ") [hereinafter cited as S. REP. No. 1196 with page references to Legislative History]; Sherwood, Must We Breathe Sulfur Oxides? Technology Rev., Jan. 1970, reprinted in LEgisLATIVE HISTORY, supra, at 1027 (technology did not exist to effectively control sulfur dioxide emissions).

7. J. Esposito, supra note 5, at 26-68 (slow pace and low funding of private auto emission control research); $i d$. at 104-11 (slow progress and low funding of sulfur dioxide control research). 
major causes of these failures. The 1970 Amendments responded to these problems and attempted to stimulate private innovation in two ways. First, section 111 required new or extensively modified sources of air pollution to meet federal new source performance standards (NSPSs), standards based on an aggressive technology-forcing definition of affordable and demonstrated control systems. ${ }^{8}$ Second, states could require existing sources to achieve technically or economically infeasible emission limitations as part of the state implementation plan (SIP) required by section $1100^{\circ}$

The state emission limitations, most of which were set in early 1972 , were intended to achieve sufficient emission reduction to allow each state to attain primary National Ambient Air Quality Standards (NAAQSs) by mid-1975. ${ }^{10}$ These standards specify the limits on pollutant concentrations in ambient air that, "allowing an adequate margin of safety, are requisite to protect the public health." 11

The decision in Union Electric Co. v. EPA affirmed the states' authority to set economically or technically infeasible emission limitations where necessary to achieve NAAQSs. ${ }^{12}$ Although the Supreme

8. Clean Air Act, $\S 111$ (a)(1), 84 Stat. 1683 (1970) (current version at 42 U.S.C.A. $\$ 7411$ (West Supp. 1978)). Although NSPSs may not be based on "purely theoretical or experimental" control capabilities, the standard need not be "routinely achieved within the industry prior to its adoption." Essex Chemical Corp. v. Ruckelshaus, 486 F.2d 427, 433-34 (D.C. Cir. 1973), cert. denied, 416 U.S. 969 (1974); accord, Portland Cement Ass'n v. Ruckelshaus, 486 F.2d 375, 391-92, 401-02 (D.C. Cir. 1973), cert. denied, 417 U.S. 921 (1974). NSPSs were meant to be revised frequently to provide incentives for the "constant improvement" of control technology and "to avoid having new plants comply with outdated standards." S. REP. No. 1196, supra note 6, at 417. No NSPSs had been revised, however, by the time the 1977 Amendments were enacted. See House COMM. ON INTERstate and foreign Commerce, Clean Air Act Amendments of 1977, H.R. Rep. No. 294, 95th Cong., 1st Sess. 11, 194 (1977). Congress now requires review of NSPSs every four years for possible revisions. Clean Air Act, $\$ 111$ (b)(1)(B), 42 U.S.C.A. $\$ 7411$ (b)(1)(B) (West Supp. 1978). Nonetheless, EPA missed both the statutory deadline and the later courtordered deadline for an important standard governing fossil-fuel powerplants. See 9 ENvir. REP. (BNA) 2246 (March 30, 1979); id. at 543 (Aug. 5, 1978).

9. Clean Air Act, $\$ 110,42$ U.S.C.A. $\$ 7410$ (a)(1) (West Supp. 1978).

10. See Clean Air Act, $\S 110(2)(2)(A)$, 42 U.S.C.A. $\$ 7410(a)(2)(A)$ (West Supp. 1978) (requiring attainment of primary NAAQSs within three years of SIP submission). At the time a state plan is submitted, a governor may petition the EPA Administrator for a twoyear extension of the compliance deadline. $I d . \$ 110(\mathrm{e}), 42$ U.S.C.A. $\$ 7410$ (e) (West Supp. 1978).

11. Id. $\S 109$ (b)(I), 42 U.S.C.A. $\S 7409$ (b)(I) (West Supp. 1978). In addition to the primary standards, secondary NAAQSs have been established to provide ambient air quality levels "requisite to protect the public welfare from any known or anticipated adverse effects." Id. $\$ 109$ (b)(2), 42 U.S.C.A. $\$ 7409$ (b)(2) (West Supp. 1978). The Act did not require these secondary standards to be met as rapidly as primary standards so long as they were met within a "reasonable time." Clean Air Act, $\$ 110(\mathrm{a})(2)(A), 42$ U.S.C.A. $\S 7410(a)(2)(A)$ (West Supp. 1978). Secondary standards do not and cannot state ambient air quality levels that would prevent all air pollution damage, however, because some pollutants will cause damage at any level. See pp. 1730-31 infra.

12. 427 U.S. 246, 265.66 (1976). 
Court held in an earlier case that states could weaken their requirements or extend a source's compliance deadline if the national ambient standards would not be violated, ${ }^{13}$ other courts held that the Act's provision aimed at the prevention of significant air quality deterioration prohibited EPA from embarking on a national policy of dispersing sources instead of abating emissions. ${ }^{14}$ Thus sources could not escape emission-control requirements by locating in clean air areas. Similarly, courts construed the term "emission limitations" to prevent sources from substituting dispersion methods such as tall smokestacks for continuous emission-reduction technology. ${ }^{15}$ These decisions prevented sources from evading emission-control requirements that often demanded the use of innovative control technology.

\section{B. The 1977 Amendments}

The Clean Air Act Amendments of $1977^{16}$ made major changes in the Act that were designed to force continued innovation. Congress

13. Train v. Natural Resources Defense Council, 421 U.S. 60 (1975) (interpreting $\$ 110$ to allow states to revise plans to grant variances not violating NAAQSs); Mision Industrial, Inc. v. EPA, 547 F.2d 123 (lst Cir. 1976) (Puerto Rico allowed to weaken sulfur oxide control regulations despite potentially hazardous pollutant Ievels derived from sulfur oxide emissions). These decisions significantly weakened the effectiveness of $\$ 110$ as a technology-forcing mechanism; by permitting the states and EPA to grant variances more easily to sources pressed by the Act's requirements, the sources most likely to need to install innovative controls could be exempted from technology-forcing. As long as NAAQSs were met, variances could be given in the form of an SIP revision made by the state with EPA approval. Train v. Natural Resources Defense Council, 421 U.S. 60, 91 (1975).

14. See Sierra Club v. EPA, 540 F.2d 1114, 1119-21 (D.C. Cir. 1976), vacated as moot, 434 U.S. 809 (1977); Sierra Club v. Ruckelshaus, 344 F. Supp. 253 (D.D.C. 1972), aff'd by an equally divided court sub nom. Fri v. Sierra Club, 412 U.S. 541 (1973).

During 1971 and 1972, EPA took the position that as long as states attained ambient air standards, it had no authority to impose further control requirements through a policy of preventing significant deterioration. See 344 F. Supp. at 254-56. This policy, together with new source performance standards for powerplants and the administration's proposal to tax sulfur emissions only in areas failing to comply with NAAQSs for $\mathrm{SO}_{2}$, would have encouraged construction of major new coal-fired electric generating capacity in clean-air western areas. See Nondegradation Policy of the Clean Air Act: Hearings Before the Subcomm. on Air and Water Pollation of the Senate Comm. on Public Works, 93d Cong., Ist Sess. 14-16, 18-19 (1973) (statement of Laurence I. Moss) [hereinafter cited as 1973 Hearings]. These new powerplants could comply with new source performance standards without using $\mathrm{SO}_{2}$ emission.control technology because local coal was low in sulfur. See note 51 infra (NSPSs set to allow compliance by burning low-sulfur fuel). Despite compliance with NSPSs, however, these new powerplants would cause considerable and avoidable air quality deterioration. See 1973 Hearings, stupra, at 14-16, 18-19. Sierra Club v. Ruckelshaus reversed this de facto EPA policy of national source dispersion on the grounds that the policy violated $\$ 101$ of the Clean Air Act.

15. See, e.g., Kennecott Copper Corp., Nev. Mines Div. v. Costle (Kennecott II), 572 F.2d 1349, 1354 (9th Cir. 1978); Big Rivers Elec. Corp. v. EPA, 523 F.2d 16, 20-22 (6th Cir. 1975), cert. denied, 425 U.S. 934 (1976).

16. Pub. L. No. 95-95, 9I Stat. 686 (1977) (codified at 42 U.S.C.A. $\$ \$ 7401-7626$ (West Supp. 1978)). 
attempted to deal with the air quality problems caused by industrial growth by adding two new parts to Title I: Part $\mathrm{C}$ codified much of EPA's former prevention-of-significant-deterioration regulations; ${ }^{17}$ Part D codified the EPA's ruling imposing strict standards on industrial growth in areas not attaining ambient air quality standards. ${ }^{18} \mathrm{New}$ sources locating in an area with air cleaner than national standards must use the "best available control technology," 10 while new sources locating in an area with air dirtier than national standards must comply with the "lowest achievable emission rate"20 attained anywhere in the country for such a source. Both requirements should spur innovation because each is defined on a case-by-case basis to incorporate the latest technological improvements; in no case may either requirement be weaker than the new source performance standards. ${ }^{21}$

In addition, the 1977 Amendments set special ambient air requirements for clean and dirty air regions. Ambient air quality requirements were tightened by limiting permissible degradation in most clean air areas to less than the national standards would permit.22 Similarly, new sources locating in nonattainment areas may not cause any additional degradation; they must pay existing sources to reduce emissions by an amount equivalent to or greater than the emissions that the new sources will produce while operating at the lowest achievable emission rate. ${ }^{23}$ These control-technology and ambient air quality requirements encourage technological innovation in expanding industries because they make industrial expansion contingent upon the development of better emission controls.

17. Clean Air Act, $\$ \S 160-169 A, 42$ U.S.C.A. $\$ \S 7470-7491$ (West Supp. 1978); 39 Fed. Reg. 42,514 (1974). These regulations govern industrial growth in clean air areas, limiting development that would degrade air quality.

18. See Clean Air Act, $\$ \S 171-78,42$ U.S.C.A. $\$ \S 7501-08$ (West Supp. 1978) (codifying EPA Ruling at 41 Fed. Reg. 55,524 (1976)).

19. Clean Air Act, $\S 165(a)(4), 42$ U.S.C.A. $§ 7475(a)(4)$ (West Supp. 1978). Best available control technology is defined on a case-by-case basis by the permitting authority, but it cannot be less stringent than what NSPSs require. Id. $\$ 169(3)$, 42 U.S.C.A. $\$ 7479$ (3) (West Supp. 1978).

20. Id. $\$ 173(2), 42$ U.S.C.A. $\$ 7503(2)$ (West Supp. 1978). Lowest achievable emission rate is to be defined on the basis of either the most stringent state requirement for such a source anywhere in the country or the most stringent emission limitation achieved in actual practice, whichever sets the tighter standard. Id. $\S 171(3), 42$ U.S.C.A. $\S 7501(3)$ (West Supp. 1978).

21. Id. $\$ \S 169(3), 171(3), 42$ U.S.C.A. $\$ \S 7479(3), 7501(3)$ (West Supp. 1978).

22. Id. $\$ \$ 163(\mathrm{~b}), 165(\mathrm{~d}), 42$ U.S.C.A. $\$ \$ 173(\mathrm{~b}), 175$ (d) (West Supp. 1978) (standards for sulfur dioxide and particulates). See id. \$ 166(a), 42 U.S.C.A. \$ 7476(a) (West Supp. 1978) (EPA must develop standards for hydrocarbons, photochemical oxidants, nitrogen oxides, and carbon monoxide).

23. Id. $\$ 173,42$ U.S.C.A. $\$ 7503$ (West Supp. 1978) (barring increases in emissions in nonattainment areas); 44 Fed. Reg. 3274 (1979) (amending EPA's nonattainment area interpretative ruling). Details about purchasing emission reductions remain unclear. 
The Amendments greatly strengthened EPA's enforcement powers, both by adding civil penalties to the Act's sanctions ${ }^{24}$ and by requiring that noncomplying stationary sources pay a penalty equal to the sum the source saved by delaying compliance beyond July 1, 1979.25 These sanctions should be more effective than the injunctive relief and criminal penalties authorized under the 1970 Amendments. ${ }^{20}$

If a source secures EPA approval to demonstrate innovative control technology, the source may be exempted from delayed compliance penalties until July 1, 1982; by that time the source will be in compliance if the demonstration is successful. ${ }^{27}$ Similar exemptions ensure that new sources that receive advance EPA approval to demonstrate innovative control technology will not be penalized if the demonstration fails. ${ }^{28}$ In addition, EPA must now review the standards for new sources every four years and revise them where control technology has improved, thereby requiring firms to keep pace with control-technology improvements. ${ }^{29}$

\section{Analyses of Technology-Forcing}

The Clean Air Amendments of 1970 induced substantial private emission-control innovation. Examination of the copper smelting and electric power industries-two industries pressed hard by the Act's re-

24. See Clean Air Act, $\$ 113(b)$, 42 U.S.C.A. $\$ 7413$ (b) (West Supp. 1978).

25. See id. $\$ 120$ (d)(2), 42 U.S.C.A. $\S 7420$ (d)(2) (West Supp. 1978).

26. Clean Air Amendments of 1970, Pub. L. No. 91-604, § 113 (current version at 42 U.S.C.A. $\$ 7413$ (West Supp. 1978)). Neither injunctive relief nor criminal penalties are well-suited to enforcing stationary source emission control requirements. It is unlikely that courts would close major industrial plants with thousands of employees or powerplants serving thousands of people. See, e.g., Kennecott Copper Corp., Nev. Mines Div. v. Train (Kennecott II), 424 F. Supp. 1217 (D. Nev. 1976), rev'd sub nom., Kennecott Copper Corp., Nev. Mines Div. v. Costle, 572 F.2d 1349 (9th Cir. 1978) (court permits smelter to remain open). Although a court could order a source to comply, the violator would have suffered no financial penalty for his delay. Criminal penalties require time-consuming investigations and trials. In addition, EPA's enforcement division has been and continues to be understaffed, inadequately informed on compliance status, and hesitant to seek legal enforcement of the Agency's administrative orders. See, e.g., GenEral Accounting Office, CED 78-165, Improvements NeEded in Controlling Major Air PolluTION SOURCEs 5-11, 15-18 (1978) (discussing hesitancy to enforce agency orders and inadequate supervision of polluters); The Continuing Crisis in Environmental Enforcement, The New Lawyer, September 1978, at 1, col. 1 (inadequate enforcement personnel in both EPA and state air pollution control agencies); Blazey, Economic Tradeoffs in Pollution Abatement, Environmental LAw, Winter 1979, at 3, col. 1 (ABA Standing Comm. on Environmental Law Newsletter) (EPA enforcement perceived as "paper tiger" by many polluters).

27. Clean Air Act, § 113(d)(4), 42 U.S.C.A. $\$ 7413(d)(4)$ (West Supp. 1978).

28. See id. $\$ 111(\mathrm{j}), 42$ U.S.C.A. $\$ 7411(\mathrm{j})$ (West Supp. 1978).

29. See id. $\S 111(\mathrm{~b})(1)(B), 42$ U.S.C.A. $\$ 7411(\mathrm{~b})(1)(B)$ (West Supp. 1978). 
quirements-proves that statutes can force technical innovation. ${ }^{30}$ Prior analyses of technology-forcing have focused on compliance as the measure of the Clean Air Act's effectiveness in stimulating innovation. ${ }^{31}$ The Act's ability to stimulate private pilot and full-scale control technology demonstrations, however, is a better measure of technologyforcing success than the extent of industry compliance with existing standards. Compliance status depends as heavily on enforcement effectiveness, revisions of standards, and other political factors as it does on control technology capabilities. ${ }^{32}$ Furthermore, installed control systems rarely represent the most current advance in control technology. ${ }^{33}$

Demonstration efforts are highly sensitive to investment risks. ${ }^{34}$ Technology-forcing requirements such as those contained in state implementation plans increase investment risks because they increase uncertainties about the number of sources needing innovative control technology and about the specifications of that technology. By the same token, technology-forcing standards such as the new source standards reduce these uncertainties, but at the expense of creating financial penalties for continued innovation. Case studies establish that government regulations can force innovation, but that the SIP and NSPS requirements are neither designed nor well-suited to do so.

\section{A. The Copper Smelting Industry}

Copper smelting is inherently dirty; the fifteen domestic primary copper smelters accounted for approximately ten percent of the national sulfur dioxide $\left(\mathrm{SO}_{2}\right)$ emissions in $1970 .^{35}$ Most of these smelters continually violated the air quality standard for $\mathrm{SO}_{2}$ issued by EPA in 1971 , and thus faced the "clean up or close" dilemma. ${ }^{36}$ For some

30. These two industries were selected for study because they both caused massive sulfur dioxide air pollution problems and neither had adequate technical solutions, yet the industries differed significantly in size, market structure, and production technology.

31. See Ayres, supra note 4, at 444-45; La Pierre, supra note 4, at 790-93. Both commentators, using compliance as the test, concluded that technology-forcing failed.

32. See note 26 supra (discussing enforcement problems); note 54 infra (weakening regulations).

33. See pp. 1724-26 infra (discussing rapid improvements in scrubber technology).

34. See R. Gilpin, Jonnt Economic Comm., Technolocy, Economic Growth, And International Competitiveness, 94th Cong., Ist Sess. 41 (1975) (economic studies conclude uncertainty and thus risk is chief obstacle to industrial innovation).

35. Copper smelters emitted about 3.6 million tons of $\mathrm{SO}_{2}$ in 1970 ; total national SO. emissions were about 34 million tons. EMission Trends, supra note 5, at 21-22, 47. Sulfur oxides, measured as $\mathrm{SO}_{2}$, were one of six pollutants for which national ambient air quality standards were set in 1971 . 40 C.F.R. $\$ 50$ (1977).

36. Only the smelter at White Pine, Michigan, owned by Copper Range Corporation, was in compliance with the EPA's standards when they were issued in 1971 and Copper Range was in compliance only because the ore smelted tended to be quite low in sulfur. Copper Range Co., Securities and Exchange Commission Form 10-K, at 9 (1975) [hereinafter 10-K forms cited as SEC Form 10-K]. 
smelters, only economically ruinous control technology was available. ${ }^{37}$

Both locally and through the federal government, the smelting firms applied massive pressure on the states to weaken SIP requirements. ${ }^{38}$ By the time state plans were submitted in January 1972 for EPA approval, control requirements for eight smelters had been deleted from the Arizona and Montana plans ${ }^{30}$ and requirements affecting several smelters in other states had been weakened. ${ }^{40}$ Although the EPA soon disapproved the SIP requirements affecting eleven of these smelters, the agency then delayed up to five years in issuing substitute emission limitations for the affected installations. ${ }^{41}$

Although this slow, weak, control program did stimulate the in-

37. See Letter from Robert Sansom, Assistant Administrator for Air and Water Programs, to Richard Ayres, Natural Resources Defense Council, at 2-3 (Dec. 7, 1973) (predicting smelter closures and production curtailments from expense of continuous emission controls) (on file with Yale Law Journal). Capital expenditures for smelter compliance have been high, totaling more than $\$ 300$ million committed or planned in mid-1973, see Office of Air Quality Planning and Standards, EPA, EPA-450/ 2-74-002a, Background Information for New-Source Performance Standards: Primary Copper, Zinc, and Lead Smelters, Vol. 1: Proposed Standards at 6-48 to 6.49 (1974) (detailing compliance plans and spending by each smelter) [hereinafter cited as SMELTER NSPS DocumeNT], and almost $\$ 1$ billion committed or spent as of Jan. 1,1978 , see, e.g., Kennecott Copper Co., SEC Form 10-K, 10 (1977) (\$390 million compliance spending); Phelps-Dodge Co., SEC Form 10-K, 5 (1977) (\$300 million compliance spending). Because of these high compliance costs, EPA modified certain regulations. See, e.g., ASARCO, Inc. v. EPA, 578 F.2d 319, 328 n.30 (D.C. Cir. 1978) (striking down EPA redefinition of modified sources made under extreme pressure from industry and Commerce Department).

38. In 1970, Arizona, Montana, and Washington adopted state emission limitations requiring $90 \%$ control of sulfur dioxide. In its proposed guidelines for the preparation of state plans, the EPA included this $90 \%$ standard as a sample emission limitation for smelters. 36 Fed. Reg. 6693 (proposed 40 C.F.R. $\$$ 51) (1971). The copper industry, working through the Office of Management and Budget, the Department of Commerce, and the White House, forced EPA to rewrite this sample standard in its final guidelines. See 40 C.F.R. $\$ 51$, Appendix B, 3.4 (1977). These changes were made after the public comment period had closed, when the final regulations were at the printers. See Implementation of the Clean Air Act Amendments of 1970, Parts 1 and 2 (Title I): Hearings before the Subcomm. on Air and Water Pollution of the Senate Comm. on Public Works, 92d Cong., 2d Sess. 4-7, 26-27 (1972) (statement of Richard E. Ayres) [hereinafter cited as 1972 Hearings].

39. See 1972 Hearings, supra note 38, at 146-47.

40. See id. at 37 (requirements for Nevada, New Mexico, and Utah).

41. EPA disapproved the Arizona, Idaho, Montana, New Mexico, Nevada, and Utah SIP requirements for thirteen copper and lead smelters as inadequate. 37 Fed. Reg. 10841, 10849, 10861, 10877, 10879, 10882, 10898 (1972) (listing disapproved SIP requirements); EPA, EPA-450/2-75-008, State Air Pollution Implementation Plan Progress REPORT, JAN. I TO JUNE 30, 1975 at 15 (1975). As of July 1975, substitute SIP requirements had been promulgated for only one smelter. Id. By 1977, EPA still had not promulgated substitute emission limitations for several smelters in Arizona and Montana. See 40 C.F.R. $\$ \S 52.125,52.134$ (1977) (Arizona sulfur oxide control strategy and compliance schedules; none listed for Phelps-Dodge or Kennecott smelters); 43 Fed. Reg. 40,240 (1978) (EPA's third proposed SIP emission limitation for Montana's Anaconda smelter; none promulgated). 
dustry to conduct major demonstrations of environmentally beneficial technology, the industry spent far more developing clean new smelting technologies than in developing controls for existing smelters. ${ }^{42}$ This concentration on new technologies failed to address the continuing problem of pollution from existing facilities. The industry conducted major demonstrations of emission-free smelting processes ${ }^{43}$ and of improved disposal methods or uses for the sulfuric acid and other sulfur compounds produced by conventional emission controls. ${ }^{44}$ An industry-funded trade association conducted more limited demonstrations of emission control devices for existing smelters' air pollution

42. The figures shown below demonstrate the heavy emphasis on new process development over new control technology development, an emphasis that continues even when development expenditures for intermittent control systems are included.

ESTIMATED ANNUAL COPPER SMELTER EMISSION-CONTROL RESEARCH, DEVELOPMENT, AND DEMONSTRATION EXPENDITURES BY RESEARCH AREA (\$ Millions)

\begin{tabular}{lccccccccc}
\hline Research Area & 1970 & 71 & 72 & 73 & 74 & 75 & 76 & 77 & total \\
\hline New Processes & 4.4 & 6.8 & 6.9 & 6.3 & 5.9 & 5.2 & 5.1 & 3.3 & 46.0 \\
Intermittent controls $^{2}$ & 0.4 & 0.9 & 0.9 & 1.3 & 1.3 & 1.3 & 1.3 & 1.3 & 8.7 \\
Byproduct disposal $^{3}$ & 0.9 & 1.2 & 1.0 & 1.0 & 1.0 & 1.0 & 1.0 & $0.5^{5}$ & 7.6 \\
$\begin{array}{l}\text { Controls for } \\
\quad \text { existing smelters }\end{array}$ & $0.8^{5}$ & 1.1 & 2.1 & 2.1 & 2.3 & 2.2 & 0.8 & $0.7^{5}$ & 12.0 \\
\hline
\end{tabular}

Table notes:

1. Anaconda Corporation's commercial demonstration of its Arbiter process accounted for the bulk of these expenditures, but all the major smelting firms mounted large and continuing efforts in this area. Expenditures are understated here because Duval Corporation's demonstration expenses are not included. See notes 43, 46, 47 infra.

2. These intermittent control system expenditures include far more computer work and far less hardware development than the other categories.

3. These efforts were directed primarily toward developing new ways to convert or dispose of the sulfuric acid produced by existing emission-control technology (acid plants) or to bypass the acid plant stage and directly produce elemental sulfur. The most noteworthy of these conversion efforts was the ASARCO-Phelps-Dodge effort to produce clemental sulfur at ASARCO's El Paso smelter. See note 46 infra.

4. These efforts were made to control the weak $\mathrm{SO}_{2}$ gas streams from reverberatory furnaces.

5. Author's estimates based on interviews and correspondence with industry personnel (sources on file Yale Law Journal).

43. See Letters from James Henderson, ASARCO, Inc. (Oct. 2, 1978); Richard Pendleton, Phelps-Dodge (Sept. 28, 1978); Ivor Pickering, Kennecott Corp. (Oct. 4, 1978); telephone interview with George Wunder, Anaconda Corp. (March 9, 1977) (letters and notes on file Yale Law Journal); Pennzoil, SEC Form 10-K, at 16, 18-19 (1972) (discussing Duval, Inc., a Pennzoil subsidiary). Anaconda and Duval each commercially demonstrated emission-free processes by building new smelters using them. Anaconda, Corporate Report 11-12 (1974); SMELTER NSPS DOCUMENT, supra note 37, at 5-15.

44. See note 43 supra (citing interviews and letters). These by-products were primarily sulfuric acid and other sulfur compounds. Estimated annual expenditures are given in note 42, supra. 
problems. ${ }^{45}$ But all these demonstrations tended to be pursued only in the infrequent cases when the EPA and the states attempted to enforce rigorous standards. ${ }^{46}$

The experience of the copper smelting industry establishes that innovation can be forced, that industries misallocate innovative efforts towards new productive technologies, and that vigorous enforcement directly affects the establishment of demonstration programs. ${ }^{47}$ These results are not unique to the copper smelting industry, however, as analysis of technology-forcing in the electric power industry demonstrates.

\section{B. Technology-Forcing in the Electric Power Industry}

When Congress enacted the 1970 Amendments, coal-fired powerplants were causing more than half the national $\mathrm{SO}_{2}$ pollution, ${ }^{48}$ and these emissions were increasing rapidly with the expansion of coal-fired generating capacity. ${ }^{49}$ Both federal and state standards developed after

45. This trade association, the Smelter Control Research Association, tested devices such as flue-gas-desulfurization (FGD) scrubbers. See Letter from Ivor Pickering, supra note 43. The association is now called the Smelter Environmental Research Association. Id.

46. For instance Duval's decision to build its own smelter was substantially affected by production curtailments placed on ASARCO's El Paso smelter in order to meet Texas air quality standards. See Pennzoil, SEC Form 10.K, at 16, 18.19 (1972); ASARCO, Inc., SEC Form 10-K, at A18 (1977) (noting reduced need to curtail production as El Paso smelter moved to comply). In another case, ASARCO, with Phelps-Dodge, demonstrated an ambitious elemental sulfur recovery process as part of a 1970 consent judgment. See N. Landau \& P. Rheingold, The Environmental Law Handbook 275 (1972) (quoting consent judgment).

47. Rather than close several smelters, Congress provided special relief in the 1977 Amendments by granting up to 10 years' additional time to comply with state emission limitations, provided that affected firms used intermittent control systems and committed "reasonable resources" to research and development of appropriate emissioncontrol technology. Clean Air Act, $\S 119$ (d)(1)(C)(ii), 42 U.S.C.A. $\S 7419$ (d)(1)(C)(ii) (West Supp. 1978). The Agency proposed to define reasonable effort in terms of emission-control demonstrations and to require affected firms to spend enough to carry out these demonstrations. See 44 Fed. Reg. 6301-02 (1979) (to be codified at 40 C.F.R. $\$ \$ 57.601-.606$ ) (nonferrous smelter order regulations). The Agency failed, however, to specify any method by which smelting firms or environmentalists could calculate how expensive an emission control demonstration program should be proposed. See id. Furthermore, "enforceable intermittent control system" may be a contradiction in terms because of severe monitoring problems. See, e.g., Natural Resources Defense Council, Comments on Proposed Rules Regarding Use of Supplementary Control Systems 11-20 (1974), reprinted in 120 Cong. Rec. 18968-72 (June 12, 1974); id. at 15, 120 Cong. Rec. 18970 (Texas official states "the only [intermittent control] system" he knew about was that "a hell of a lot of copper is smelted [at El Paso plant] when the wind blew towards Mexico").

48. See Emission Trends, supra note 5, at 22, 39-44. Powerplants emitted about 19.4 million tons of $\mathrm{SO}_{2}$ in 1970, nearly seven times their emissions in 1940. See id. at 39, 44. Powerplants also create a severe nitrogen oxide (NO $\mathrm{N}_{\mathrm{s}}$ ) problem: they emitted about 4.7 million tons, or $20 \%$ of national $\mathrm{NO}_{\mathrm{x}}$ emissions in 1970 . Id. at 44 .

49. See EPA, Background Information for Proposed New-Source Performance Standards: Steam Generators, Incinerators, Portland Cement Plants, Nitric Acid Plants, 
the 1970 Act required powerplants to burn scarce low-sulfur fuel or develop technically formidable $\mathrm{SO}_{2}$ controls, commonly known as "scrubbers." 50 As state plans were submitted and approved in 1972, it soon became clear that there would be a massive shortage of coal or oil clean enough to meet standards if scrubbers were not developed quickly. ${ }^{51}$ Between 1972 and 1974, the feasibility of scrubbers emerged as the major issue in the struggle between the EPA and the utilities over compliance with $\mathrm{SO}_{2}$ emission limitations. ${ }^{52}$ The agency confronted technical objections in extensive public hearings in $1973^{53}$ and followed in 1974 with a vigorous enforcement program. ${ }^{54}$

Despite the early and well-publicized failures of several scrubber

Sulfuric Acid Plants 14 (1971) (35 fossil-fuel powerplants added each year) [hereinafter cited as Steam Generator NSPS Document]. Analyses presented during the 1970 hearings on the Clean Air Act indicated a possible doubling of $\mathrm{SO}_{2}$ emissions from powerplants between 1970 and 1980 unless controls were imposed. See, e.g., Sherwood, supra note 6, at 1028-29.

50. See 40 C.F.R. $\$ 50.5$ (1977) (NAAQSs for SO 2 ); 40 C.F.R. $\$ \S 60.40-46$ (1977) (powerplant NSPSs). EPA has proposed controversial revisions of this standard. See 43 Fed. Reg. 42,154 (1978) (explaining EPA rationale).

51. New-source standards for powerplants were set with regard to the "desirability of setting sulfur dioxide standards that would allow the use of low-sulfur fuels as well as fuel cleaning, stack gas cleaning, and equipment modifications." STEAM GeNERATOR NSPS Document, supra note 49, at 7. See National Electric Reliability Council, Assessment of the State-of-Technology of air Pollution Control Equipment and of the Impact of Clesan Air Regulations on the Adequacy of Electric Power Supply of North AMERICAN BULk Power Systems II-4 to II-5, III-5 to III-6 (1972) (noting probable shortages of low-sulfur fuels); Interagency Sulfur Oxide Control Technology AssessMENt PANel (SOC'TAP), SOCTAP Final REPort i, 68 (1973) [hereinafter cited as SOCTAP REPORT]. By the end of 1972 , only eight of more than 200 electric utilities in the United States had begun demonstrating scrubbers. EPA, Office of Energy, Minerals and Industry, Summary of the Operability of Flue Gas Desulfurization Technology 1-2 (Sept. 14, 1977) (Report to the President's Office of Energy Policy and Planning) (on file with Yale Law Journal) [hereinafter cited as FGD Operability].

52. See, e.g., Buckeye Power, Inc. v. EPA, 481 F.2d 162 (6th Cir. 1973) (remand of state plan for consideration of technical feasibility issues); Duquesne Light Co. v. EPA, 481 F.2d I (3d Cir. 1973) (remand of certain emission limitations for consideration of feasibility). Several important SIPs were later vacated or modified in state courts or administrative proceedings, exempting 102 of the nation's 394 coal-fired powerplants from cmission controls. EPA, EPA Enforcement: A Progress Report, Degember 1974 to DeCEMBER 1975, at 11-12 (1976) (discussing legal difficulties of Ohio, Indiana, and Illinois plans, as well as other powerplant compliance problems) [hereinafter cited as ENFORCEMENT PROGRess].

53. See EPA, Report of the Hearing Panel: National Public Hearings on Power Plant Compliance with Sulfur Oxide Air Pollution Regulations (1974) [hereinafter cited as Hearinc Panel Report].

54. See Enforcement Procress, supra note 52, at 11-12. With considerably less publicity, however, the EPA also encouraged states to revise and weaken state plans in order to reduce demand for low-sulfur fuel or scrubbers. See EPA, EPA-450/3-75-053a, 1 National Summary of State Implementation Plan Reviews (Section 4 ESECA) 1-2, 6 (1975). 
demonstration programs, ${ }^{55}$ the state and federal requirements forced relatively rapid development, demonstration, and use of workable $\mathrm{SO}_{2}$ control technology. At the time federal standards were set in 1971 for new coal-fired powerplants, there were no commercially demonstrated flue-gas-desulfurization (FGD) systems. ${ }^{56}$ The systems tested broke down frequently and achieved removal efficiencies barely adequate to achieve the standard.57 But by the time the EPA began to reevaluate the powerplant standards in 1977, new model scrubbers operated properly about ninety percent of the time, up from about fifty percent in $1971 . .^{58}$ Removal efficiencies improved from seventy-five percent in 1971 to better than ninety-five percent for some units in 1976.59

The SIP and NSPS standards made the crucial difference in forcing the commercial demonstration of scrubber technology. ${ }^{00}$ The standards forced control technology vendors and utilities to solve the difficult design problems of sophisticated large-scale systems, ${ }^{61}$ and allowed vendors to transfer and demonstrate EPA and Japanese process-chemistry improvements on large-scale systems. ${ }^{62}$ Both vendors and utilities

55. Two early systems failed full-scale tests: limestone injection systems failed at Union Electric's Meramec plant during testing between 1968 and 1971 and catalytic oxidation failed at Illinois Power's Wood River plant between 1972 and 1974. See FGD Operability, supra note 51, at 2-1 to 2-3 (Meramec and Wood River scrubbers were only two full-scale units discontinued solely because of severe operational difficulties).

56. See Essex Chemical Corp. v. Ruckelshaus, 486 F.2d 427, 440 (D.C. Cir. 1973), cert. denied, 416 U.S. 969 (1974) (scrubbers approached but did not achieve NSPS requirements).

57. See STEAM GENERATOR NSPS Document, supra note 49, at 10.11 (removal efficiency); PEDCo Environmental Specialists, Inc., Summary Report, Flue Gas Desulfurization SysteMs, SEPTEMBER-OctoBer 1976 at 35-199, 255.93 (describing FGD operations including early operation difficulties) [hereinafter cited as PEDCo REPORT].

58. See FGD Operability, supra note 51, at 3-1. These operability figures of $90 \%$ compare favorably with overall powerplant operability of $75 \%$ to $80 \%$. Id. at $3-5$. The terms operability, availability, and reliability are often used interchangeably in reporting scrubber operations. See PEDCo REPORT, supra note 57, at 307 (defining terms).

59. See Steam Generator NSPS Document, supra note 49, at 10-11 (two 1971 demonstration units approached $73 \%$ removal efficiency); FGD Operability, supra note 51 , at Table 3-I (noting nine units achieving $95 \%$ removal efficiencies some or all the time).

60. See FGD Operability, supra note 51, at 1-2 to $1-3,2-1$ to $2-3$ (11 types of scrubbers demonstrated in response to federal standards; several successful systems closed after regulations weakened); note 67 infra (abandonment of costly but successful demonstrations).

61. Commission on Natural Resources, National academy of Sciences, National Academy of Engineering, National Research Council, Air Quality and Stationary Source Emission Control, Sen. Serial No. 94-4, 94th Cong., lst Sess. 386-88 (Public Works Comm. Print 1975) (many problems not apparent until full-scale systems tested) [hereinafter cited as NAS REPORT].

62. Process chemistry refers to the overall chemistry of scrubber operations; maintaining the proper chemical balances in a full-scale scrubber presented difficult problems. See id. at 386-88. Despite some substantial vendor efforts, EPA and Japanese demonstrations were more successful than the vendors' in solving these process-chemistry problems. See FGD Operability, supra note 5I, at 3-1; SOCTAP REPORT, supra note 51, at ii, 1-3. As the two tables, infra, illustrate, EPA has spent far more on scrubber development than the vendors. (These figures slightly understate the vendors' role in emission-control innovation because the Electric Power Research Institute subcontracts much of its work to them and 


\section{Technology-Forcing}

tended to leave the difficult and expensive process-chemistry problems to the EPA, however, concentrating instead on cheaper and easier mechanical problems. ${ }^{63}$ In addition, utilities' work emphasized new, low-polluting generating technology, just as the smelting companies emphasized clean new production processes. ${ }^{64}$

Although the state and federal requirements eventually stimulated the critical demonstrations, they also created some severe difficulties for potential innovators. The SIP requirements stimulated almost all the private scrubber demonstrations before 1976, but the use of air-quality

because manufacturers incorporate new ideas into full-scale installations so that some development costs are treated as a cost of sales and not reported as research. See McIlvaine Company, $\mathrm{SO}_{x}, \mathrm{NO}_{x}$, and Particulate Research and Development and Installed Cost Projections 8 (1977).)

TABLE 1: Vendors' Projected Scrubber and Particulate Control Demonstration Expenditures (\$ Millions)

\begin{tabular}{|c|c|c|c|c|}
\hline & \multicolumn{2}{|c|}{1977} & \multicolumn{2}{|c|}{1982} \\
\hline & \% Sales & $\$$ & \% Sales & ş \\
\hline $\begin{array}{l}\text { FGD Processes } \\
\text { Particulate Controls: }\end{array}$ & $3.5 \%$ & 4.8 & $2.5 \%$ & 10.9 \\
\hline Fabric Filters & $2.2 \%$ & 4.4 & $2.3 \%$ & 10.2 \\
\hline Precipitators & $1.3 \%$ & 3.0 & $1.4 \%$ & 7.5 \\
\hline Total & & 12.2 & & 28.6 \\
\hline
\end{tabular}

Source: McIlvaine Co., $\mathrm{SO}_{x}, \mathrm{NO}_{x}$, and Particulale Research and Development and Installed Cost Projections 11 (1977).

TABLE 2: EPA $\mathrm{SO}_{2}$ Emission-Control Demonstration Expenditures, 1970-76 ( $\$$ Millions)

$\begin{array}{ll}\text { FGD Processes } & \$ 81.4 \\ \text { Fluidized Bed Combustion } & \$ 19.4 \\ \text { Coal Cleaning } & \$ 21.0\end{array}$

Source: Merilee Merimon \& Bill Rice, Office of Energy, Minerals, and Industry, EPA (file search December 1976).

Note: EPA's predecessor agency, the National Air Pollution Control Agency, spent about $\$ 15$ million on FGD work between 1967 and 1969.

63. See FGD Operability, supra note 51, at 3-1 (noting EPA process chemistry work; vendor improvements in selection of materials); NAS REPORT, supra note 61, at 393-94, 456 (noting shortages of chemical engineers working for utilities); note 68 infra (same).

64. See Electric Power Research Institute, EPRI RD-4, Digest of CuRrent Research IN THE ELECTRIC UTILITY INDUSTRY 156-210 (1978) (summarizing new fossil-fuel processing and generating demonstrations performed by or for utility industry under institute's auspices). The Electric Power Research Institute also conducts major air pollution control demonstrations, id. at 220-68, and will spend more than $\$ 65$ million between 1979 and 1983 on this work, more than a tenth of its research budget for fossil fuel and advanced systems demonstrations, EPRI, PS-831-SR, Research and Development Program Plan for 1979-1983 at 2 (1978). This compares with $\$ 46$ million spent by the entire industry on all research in 1970. See Federal Power Commission, Statistics on Privately Owned Electric UTilities in the UNITED STATES, 1970 at 763 (1971). 
modeling or other crude methods of setting these limitations, ${ }^{65}$ and the possibility of revisions in the state plans, made litigation and political opposition more attractive in many cases than innovation. ${ }^{\circ 0}$ State revisions of emission limitations caused several promising scrubber demonstrations to be abandoned. ${ }^{67}$

The vulnerability of SIP emission limitations to challenge and revision discourages utilities from conducting emission-control demontrations. Innovation is further hampered by utility ratemaking practices that limit the extent to which research expenditures can be recovered. ${ }^{68}$ From a utility's perspective, using low sulfur fuel is preferable because it does not saddle the utility with useless and possibly valueless capital equipment if the state requirements are weakened, and because it allows expenses to be recovered quickly through fuel ad-

65. Air quality modeling generally refers to computer simulation of the ambient air quality effects of pollutant emissions. The substitute Ohio plan promulgated by EPA in 1976 has been challenged specifically with regard to the accuracy of the air quality models used to develop the emission limitations. See Cincinnati Gas \& Elec. Co. v. EPA, 578 F.2d 660 (6th Cir. 1978), cert. denied, 99 S. Ct. 1017 (1979) (disapproving certain aspects of EPA's model); Cleveland Elec. Illuminating Co. v. EPA, 572 F.2d 1150 (6th Cir.), cert. denied, 99 S. Ct. 278 (1978) (upholding use of a different EPA model).

66. The Amcrican Electric Power Company, for instance, spent about $\$ 3.6$ million in 1974 on controversial advertising attacks on scrubbers and government restraints on mining low sulfur coal. These advertisements advocated the use of tall stacks instead of scrubbers. See American Electric Power, Annual Report 1974 at 16.17 (1975) (text of 36 ads); Telephone Interview with William Corbitt, Vice President, American Electric Power Co. (Jan. 6,1977 ) (estimating costs of ads at about $\$ 100,000$ each) (notes on file Yale Law Journal). The long absence of $\mathrm{SO}_{2}$ emission controls in Ohio's SIP demonstrates the success of unrelenting opposition to controls. See Cleveland Elec. Illuminating Co. v. EPA, 572 F.2d 1150, 1156-57 (6th Cir.), cert. denied, $99 \mathrm{~S}$. Ct. 278 (1978) (noting long absence of controls). The Ohio Environmental Board of Review found that the Ohio EPA's "main motivation" in proposing weakened emission controls "was to seek an accommodation with the electric utility companies and other large industrial sources." 5 ENVIR. REP. (BNA) 898-99 (1974).

67. See FGD Operability, supra note 51 , at 2-1 to 2-3 (identifies eight successful demonstrations abandoned in part because actual or anticipated regulations were weakened, permitting compliance without scrubbers).

68. Utilities favored burning low-sulfur coal instead of using scrubbers because fuel costs could be recovered immediately through automatic fuel adjustment clauses but scrubber construction costs could not be recovered until construction was completed and rate increases were approved in hearings by the state public utility commission. See Enforcement Progress, supra note 52, at 11; Hearing Panel Report, supra note 53, at I, 8, 10; Ayres, supra note 4, at 446-47, 463-64. Utility willingness to demonstrate vendors' advanced technologies, including advanced controls, strongly affects the rate of innovation, see Hughes, Scale Frontiers in Electric Power, in Technological Change in ReguLATED INDUSTries 44.45 (W. Capron ed. 1971), because electric utilities cannot have corporate links with equipment manufacturers and so cannot profit from the sale of the technologies they successfully demonstrate, see Public Utility Holding Act of 1935, § 13, 15 U.S.C. $\$ 79 \mathrm{~m}$ (1976) (barring corporate links). Thus utilities moved too slowly in the 1960s to build the necessary technical staffs to handle the engineering requirements of nuclear power equipment orders; the pattern repeated itself with FGD equipment in the early 1970s. SOCTAP REPORT, supra note 51, at 66-67. 
justment clauses. SIP deadlines tend to reinforce this preference for low-sulfur fuel over innovative capital expenditures. ${ }^{69}$

In contrast to the uncertainties attending SIP emission limitations, the federal new source performance standards for new fossil-fueled powerplants confronted utilities with a single standard for emissions from those plants. Challenging the NSPSs proved less attractive and effective than SIP challenges because the Act had settled the issue of which plants had to meet the standards by requiring all new ones to do so, and because the standards themselves were based on reasonably determinable facts: the capabilities of the most advanced emissioncontrol system affordable by the industry. Confronted with the choice between the long-term use of low-sulfur fuel or installation of scrubbers, a number of utilities chose to install scrubbers on their new plants. $^{70}$

By the time these new plants came on line in 1975 and 1976, however, scrubbing technology had advanced to the point where the newsource standards for powerplants could be achieved routinely; building these scrubbers to meet new-source standards did less than earlier state-induced demonstrations to advance control technology capabilities. Moreover, new source requirements discouraged utilities from seeking further improvements in removal efficiency, because these improvements might then serve as the basis for expensive new standards. ${ }^{71}$ Although EPA undertook scrubber demonstrations ${ }^{72}$ and the states imposed SIP emission limitations more stringent than NSPS requirements, ${ }^{73}$ barriers to innovation still existed.

\section{Economic and Political Limitations of Technology-Forcing}

The experiences of the copper smelting and electric power industries demonstrate that emission-control innovation can be forced but that

69. See Ayres, supra note 4 , at $463 \cdot 64$.

70. Between 1975 and 1977,13 new powerplants came on line with scrubbers, seven of which had to meet state emission limitations stricter than NSPS requirements. Confronted with these stricter standards, some of these plants commercially demonstrated limestone/ flyash scrubbing, an important system for low-sulfur western coals. See PEDCo REPORT, supra note 57, at 5-8 (identifying stringency of regulations facing each scrubber installation); FGD Operability, supra note 51, at 1-2, 1-3 (identifying systems as new or retrofit and specifying system type).

71. Office of Energy, Minerals, and Industry, EPA, The Federal Program in Coal Cleaning 5 (Aug. 29, 1977) (report to the President's Office of Energy Policy and Planning) (NSPSs "discourage [research] efforts by coal users, since control technology breakthroughs will not be used to reduce costs, but to tighten standards.") [hereinafter cited as Coal Cleaning Report]. Of 27 scrubbers installed before 1975, only three were installed on new sources. See FGD Operability, supra note 51, at 2-1.

72. Of seven utility scrubber demonstrations begun in 1972 , four were funded in whole or in part by EPA. SOCTAP REPORT, supra note 51, at 21, 23, 30.

73. See note 70 supra. 
current SIP requirements and NSPSs sometimes impede innovation. The states' reliance on individually tailored emission limitations impedes innovation because it necessarily creates uncertainties about the permanence and stringency of these limitations, and so encourages litigation, political opposition, and technical hesitation. These uncertainties, concerning both the size of the market for technologically improved pollution controls and the market's technical requirements, increase investment costs. ${ }^{74}$ As the case studies establish, uncertainties increase the risks of emission-control innovation, making higher profits necessary to attract investment. Thus, increased risk discourages innovation. Although vigorous enforcement can overcome these problems, the primary goal of enforcement officials is compliance and not technology-forcing. ${ }^{75}$ Consequently, enforcement officials will often be tempted to decrease emission limitations to routinely achievable levels in exchange for swift compliance. ${ }^{70}$ Such compromises seem inevitable, and occasionally appropriate, but they severely limit the technologyforcing effectiveness of SIP and NSPS enforcement.

The new source requirement reduces these uncertainties by setting an industry-wide technical goal for a clearly defined market: all new plants. The NSPS penalizes polluting firms that demonstrate improvements over NSPS, however, because these improvements become the basis for expensive new standards applied to the firm's future plants. ${ }^{77}$ The 1977 Amendments attempted to solve these problems by overcoming the regulatory lag in revising NSPSs. The Amendments did so by requiring periodic revisions and by requiring that all new facilities face case-by-case determinations of the best available control technology to be used, with the NSPS serving as the minimum standard. ${ }^{78}$ These case-by-case determinations are similar to the combina-

74. Aggravation or reduction of market uncertainty is particularly important since "according to the results of four empirical studies, between two-thirds and three-quarters of innovations are initially stimulated by a clear definition of market needs." OrGanizAtion for EConomic Co-operation and Development, The Conditions for Success in TECHNOLOGICAL INNOVATION 12 (1971).

75. See EPA, EPA-450/3-75-053a, 1 National Summary of State Implementation Plan Reviews (SECTION 4 ESECA) 1, 6 (1975) (EPA officials encouraged states to weaken SIP requirements for many powerplants under agency's "clean fuels" policy); notes 26, 54 supra (discussing enforcement).

76. Bargaining over emission limitations between the state agency (or EPA) and the affected source scems incvitable. Regulators will tend to bargain away technology-forcing requirements for compliance with lesser standards. The bargaining tendency was verified in the water pollution control context. See National Commission on Water Quality, Staff Draft Report, V-30 (1975).

77. See LA Pierre, supra note 4, at 774; Coal Cleaning Report, supra note 71, at 5.

78. See p. 1717 supra. 
tion of SIP and NSPS requirements that hastened demonstration of scrubbers on Western powerplants. ${ }^{79}$

Despite these statutory changes, federal emission control demonstrations must still play a significant role in overcoming the barriers to innovation caused by the new-source standards. Control technology vendors are usually too small to demonstrate innovative control technologies on a commercial scale without cooperation by the affected industry. ${ }^{80}$

Both state emission limitations and federal new source standards generally state their requirements as performance standards: specified emission limitations that must be achieved by a certain date. ${ }^{81}$ Congress chose this form of expressing standards instead of specifying control technology in order to avoid "freezing the state of the art." 82 Although performance standards do not discourage emission control innovation in general, the compliance deadlines discourage capital intensive means of compliance for existing plants. ${ }^{83}$ The case studies

79. See note 70 supra (discussing flyash scrubbers).

80. Although historically vendors developed many utility innovations, improvements such as new combustion methods are now too expensive for any single vendor, utility, or group of vendors to develop. See Oversight Hearings: Coal Combustion R.D.نD. for Utility Powerplants and Industrial Users: Hearings before the Subcomm. on Energy Research, Development and Demonstration (Fossil Fuels) of the House Comm. on Science and Technology, 94th Cong., 1st Sess. 635-36 (1975) (Electric Power Research Institute submission). Federal demonstration efforts, however, cannot overcome these vendor problems alone. The expense of conducting numerous full-scale demonstrations is too great, see Bonine, supra note 3, at 9-10 (discussing congressional failures to appropriate sums authorized for demonstrations); Ayres, supra note 4, at 465, and federal demonstrations do too little to build vendor or utility expertise in the construction and operation of innovative emission controls. See FGD Operability, supra note 51, at 3-1, 3-5, 6-2 (discussing improved scrubber design and operability with increased utility experience with FGD).

81. See, e.g., note 50 supra (powerplant NSPS); Cleveland Elec. Illuminating Co. v. EPA, 572 F.2d 1150, 1159 (6th Cir.), cert. denied, 99 S. Ct. 278 (1978) (Ohio SIP emission limitations expressed as performance standards). "Standards of performance" refers to the degree of emission control that can be achieved through process changes, operation changes, direct emission control, or other methods. S. REP. No. 1196, supra note 6, at 417.

82. S. REP. No. 1196, supra note 6, at 417 (EPA Administrator should not make technical judgment as to how standard should be implemented); see id. at 409 (not committee's intention to lock in control technology); Air Pollution-1970 (Part 2): Hearings Before the Subcomm. on Air and Water Pollution of the Senate Comm. on Public Works, 91st Cong., 2d Sess. 454-63 (1970) (statement of Aaron Teller) (need for control technology innovation and dangers of locking in control technology).

83. The compliance deadlines favor expensive process changes such as the use of low sulfur fuel, rather than cheaper but more capital-intensive control equipment like scrubbers. See p. 1727 supra (SIP deadlines favor low sulfur fuel use). In addition, the deadlines favor use of package control technologies like scrubbers, which can be added to existing types of production technology, rather than capital-intensive changes in production technology itself. Fundamental process changes such as fluidized-bed combustion or new smelting processes usually take too long to develop and install. See Letter of Richard Pendleton, supra note 43 (time needed for fundamental process changes). Even though NSPSs give compliance extensions for development and use of innovative controls, the compliance deadline "is much too short to allow significant depreciation of capital... 
establish, however, that there is a strong tendency towards capitalintensive controls in new plants, where there is time to build fundamentally clean production processes. ${ }^{84}$

\section{Improved Technology-Forcing: A Proposal}

The case studies illustrate the economic and political difficulties of the Clean Air Act's technology-forcing provisions. Two fundamental decisions of the Act-to rely on ambient air quality standards and on state-by-state air quality control-also create technology-forcing difficulties.

\section{A. Limitations on SIP Technology-Forcing}

\section{Limitations of Ambient Air Quality Standards}

If the achievement of primary and secondary national air quality standards fully prevented air pollution damage, the SIP process, with all its faults, might force control technology improvements sufficent to maintain such protection. But NAAQSs, particularly secondary NAAQSs, ${ }^{85}$ do not and cannot reflect some important types of air pollution damage, because certain kinds of damage are caused much more by the quantity of pollutant emitted than by the pollutant concentration.

Secondary NAAQSs were supposed to set pollutant concentrations in ambient air low enough to protect the public "from any known or anticipated adverse effects of air pollution-including effects on soils, water, vegetation, man-made materials, animals, wildlife, visibility[,] climate, and economic values." 80 The secondary standards do not and cannot state proper levels for sulfur dioxide and nitrogen oxide $\left(\mathrm{NO}_{\mathrm{x}}\right)$ pollution, however, because damage occurs at any level of emission. Although these substances cause severe problems when their concentrations exceed ambient standards, significant problems also result from

[and so does] not provide any real incentive to build a commercial facility that has potential benefits but a finite risk of not achieving performance standards." Steven Reznek, Domestic Policy Review of Industrial Innovation 36 (1978) (EPA Office for Energy, Minerals, and Industry). The compliance deadlines and performance standards also discourage capital intensive process changes such as physical coal cleaning, which generally cannot achieve standards without using scrubbers but have significant economic and emission control benefits. See Coal Cleaning Report, supra note 71, at 1-7. This effect is unfortunate because such process changes can often significantly reduce compliance costs. See id. at 3-4; cf. Reznek, supra, at 19-21 (process changes and savings in water pollution control).

84. See notes $42 \& 64$ supra (discussing concentration on new process demonstrations).

85. Clean Air Act, $\S 109(b)(2), 42$ U.S.C.A. $\$ 7409(b)(2)$ (West Supp. 1978).

86. S. REP. No. 1196, supra note 6, at 411 . 


\section{Technology-Forcing}

the quantity of total emissions. Acid rainfall is an especially good example of this. ${ }^{87}$ Similarly, other kinds of air pollution damage may be abated only through large reductions of total $\mathrm{SO}_{2}$ emissions. Most $\mathrm{SO}_{2}$ emissions break down into sulfate pollutants that can, at pollutant concentrations much lower than $\mathrm{SO}_{2}$ standards, cause both serious health problems and regionwide reductions in visibility. ${ }^{88}$ To compound the difficulty, these sulfate pollutants travel many hundreds of miles, making proper monitoring, modeling, and enforcement impossible. Thus severe air pollution damage will continue even if NAAQSs are met.

\section{Limitations of State-by-State Control}

Reliance on state-by-state air quality regulation has two institutional limitations that may impair technology-forcing. First, reliance on SIPs permits state law to undermine achievement of the federal statutory objective of technology-forcing. In Union Electric, the Supreme Court held that so long as states did not interfere with the primary congressional purpose of promptly attaining national air quality standards, the states could consider technological and economic infeasibility claims. ${ }^{39}$ Stationary sources may raise these infeasibility claims before state agencies when SIPs are formulated, ${ }^{90}$ seek variances from states at a later time (subject to EPA approval), ${ }^{91}$ or raise these claims in the state courts. ${ }^{92}$ These claims have been advanced with some success as

87. Normal rainfall is slightly acidic because of atmospheric carbon dioxide and resultant carbonic acid. Acid rainfall in the eastern states has been increasing with increases in $\mathrm{SO}_{2}$ and $\mathrm{NO}_{\mathrm{x}}$ emissions, NAS REPORT, supra note 61, at xxvii, and now adversely affects most of the United States east of the Mississippi River, id. at 302-03. Powerplant $\mathrm{SO}_{2}$ and $\mathrm{NO}_{\mathrm{X}}$ emissions are the primary source of these problems, largely because tall stacks promote long-distance transport of these emissions and conversion to sulfate and nitric acid. See $i d$. at 281-85. Although sulfates account for most of the rainfall acidity, nitric acid now accounts for about a quarter, and this share continues to increase. See $i d$. at 302-03. This rainfall causes several hundred million dollars worth of damage annually, from serious water pollution, crop and forest damage, damage to materials, and disruption of ecosystems. See Staff of House Subcomm. on The Environment and The atmosphere, Review of Research Related to Sulfates in the Atmosphere, 94th Cong., 2d Sess. 17 (Comm. Print 1976) [hereinafter cited as Sulfate Research REview]; USDA Forest Service, Generat Technical Report Ne-23, Proceedings of the First International Symposium on Acid Precipitation and the Forest Ecosystem (1976) (discussing acid rainfall problems in North America and Europe and impacts on forests).

88. See NAS REPORT, supra note 61, at 181-82 (visibility); Sulfate Research REview, supra note 87, at 13-16 (potentially serious health effects of sulfates).

89. 427 U.S. at 266.

90. Id.

91. Id.; Train v. Natural Resources Defense Council, 421 U.S. 60 (1975).

92. Union Electric Co. v. EPA, 427 U.S. 246, 266-67 (1976); Commonwealth Edison Co. v. Pollution Control Bd., 25 Ill. App. 3d 271, 286-88, 323 N.E.2d 84, 95-96 (1974), aff'd on other grounds, 62 Ill. 2d 494, 343 N.E.2d 459 (1976). 
a bar to enforcement of state standards. ${ }^{93}$ These claims may also be used to delay federal enforcement: federal district courts sometimes abstain from enforcement, pending state action. ${ }^{94}$ Although it may be appropriate in some cases to grant variances or to abstain from enforcement, these practices, like the bargaining inherent in enforcement actions, will limit the effectiveness of state technology-forcing.

The second limitation of state technology-forcing is that state plans do not adequately address interstate air pollution problems. States have no incentive to impose controls to abate problems in downwind states. ${ }^{95}$ The most severe interstate air pollution problems, such as acid rainfall, present extraordinarily difficult air quality modeling problems because of both the long distances that pollutants travel and the complex chemistry involved. ${ }^{96}$ These kinds of problems will be resolved only through national reductions in $\mathrm{SO}_{2}$ and $\mathrm{NO}_{\mathbf{I}}$ emissions. Failure to address these interstate problems will place severe limitations on the continued effectiveness of technology-forcing.

\section{B. Emission Penalties and Technology-Forcing}

If technology-forcing is to provide the control technology necessary to achieve Congress's objective of preventing air pollution damage

93. See Commonwealth Dep't of Environmental Resources v. Pennsylvania Power Co., 461 Pa. 675, 337 A.2d 823 (1975) (opinion of Jones, C.J., one justice concurring, four justices concurring in result) (impossibility is defense to contempt proceedings brought to compel utility installation of $\mathrm{SO}_{2}$ and particulate matter controls). The Pennsylvania Supreme Court effectively exempted the utility from state emission limitations. See Comment, Technology Forcing Under the Clean Air Act: The Electric Utility Dilemma, 38 U. PitT L. Rev. 505, 525-26 (1977). The court did so two years after EPA concluded that scrubber technology had been demonstrated, eliminating any dilemma. See HeArinc PaneL REPORT, supra note 53, at 27-30. The Pennsylvania courts have narrowly construed this decision and have not permitted technical infeasibility claims to be raised as a defense to the enforcement of consent decrees for the cleanup of coke ovens and steel mills. See Commonwealth Dep't of Environmental Resources v. Bethlehem Steel Corp., 469 Pa. 578, 367 A.2d 222 (1976), cert. denied, 430 U.S. 955 (1977) (holding consent decree enforceable during period where firm seeks modification from administrative agency); Rochez Bros., Inc. v. Dep't of Environmental Resources, 18 Pa. Commw. Ct. 137, 146, 334 A.2d 790, 796 (1974) (construing lower court decision in Pennsylvania Power to permit impossibility defense only in contempt proceedings).

94. See, e.g., United States v. Interlake, 429 F. Supp. 193 (N.D. Ill. 1977).

95. States may petition the EPA Administrator for action against sources in other states that violate the petitioning state's standards. Clean Air Act, $\$ 126(\mathrm{~b})$, 42 U.S.C.A. $\$ 7426$ (b) (West Supp. 1978). Pennsylvania has requested the EPA to study the adverse air quality impacts on Pennsylvania caused by Ohio and West Virginia powerplant $\mathrm{SO}_{2}$ emissions. See Letter from Maurice K. Goddard, Dep't of Environmental Resources, to Douglas Costle, EPA Administrator (Dec. 13, 1977), reprinted in TEKNEKRoN, INC., IMpact of Long-Range Transport of Pollutants on Air Quality in the Commonwealth of Pennsylvania: Interim Report A-12 to -13 (1978). EPA has not yet issued regulations to implement this provision.

96. See NAS REPORT, supra note 61, at 4-14 (discussing atmospheric chemistry); SULFATE RESEARGH REVIEw, supra note 87, at 5-8 (same). 


\section{Technology-Forcing}

completely, ${ }^{97}$ it must have a legal basis and enforcement mechanism in addition to existing state plans and new-source standards. In order to provide an effective basis, both the EPA and Congress must recognize that, regardless of pollutant concentrations, the total quantity of $\mathrm{SO}_{2}$ and $\mathrm{NO}_{\mathrm{x}}$ emissions $^{98}$ creates severe environmental problems that will continue and grow despite industry compliance with primary and secondary ambient air quality standards.

Congress should overcome present limitations on technology-forcing by amending the secondary NAAQS provision ${ }^{99}$ to require private emission-control demonstration spending equivalent to the pollution damage that would be caused by $\mathrm{SO}_{2}, \mathrm{NO}_{\mathbf{x}}$, and other emissions after present ambient standards are met. ${ }^{100}$ This demonstration requirement should be imposed by means of a uniform national emission penalty for each relevant pollutant. ${ }^{101}$ Each source's required spending would be based on total annual emissions multiplied by the appropriate penalty rates. ${ }^{102}$ Money not spent on EPA-certified demonstrations would be paid into the federal treasury. ${ }^{103}$

97. See p. 1732 supra.

98. See id. \& notes $94-95$ supra.

99. Clean Air Act, $\S 109$ (b)(2), 42 U.S.C.A. $\S 7409$ (b)(2) (West Supp. 1978).

100. In order to force innovation by sources emitting hazardous air pollutants as defined under $\S 112$ of the Clean Air Act, 42 U.S.C.A. $\$ 7412$ (West Supp. 1978), $\$ 112$ 's standards are similar in form to new-source standards, and like them may retard innovation in the control of dangerous emissions. The experience of the Occupational Safety and Health Administration in regulating carcinogens in the workplace and the severe prob. lems OSHA has confronted concerning economic and technological feasibility strongly suggest the need for innovation in the control of these hazardous emissions. See Berger \& Riskin, Economic and Technological Feasibility in Regulating Toxic Substances Under the Occupational Safety and Health Act, 7 Ecology L.Q. 285, 311-21, $346-58$ (1978) (discussing feasibility problems of various OSHA standards for carcinogens).

101. There are three reasons for this national approach: the technological benefits of demonstrations are national, the environmental damages involved spread across many states, and a national approach is consistent with the Clean Air Act's strong policy against regional discrimination. The Act strongly emphasizes national standards. Clean Air Act, $\$ \S 109,111,112,202,211,42$ U.S.C.A. $\$ \S 7409,7411,7412,7521,7545$ (West Supp. 1978).

102. The primary purpose of this approach is to force continued commercial demonstrations of full-scale emission controls or fundamentally clean production technology, so the full penalty rate should be phased in over several years in order to give affected firms time to carry out orderly demonstration programs. If the full penalty rate were charged in the initial years, the affected industries would have difficulty spending much of the penalty on demonstrations, since demonstration efforts take time to plan and perform.

Although joint efforts should not be entirely forbidden, they must be closely monitored to prevent deliberate obstruction of technical progress as well as antitrust violations. See, e.g., United States v. Automobile Mfrs. Ass'n, 307 F. Supp. 617 (C.D. Cal. 1969), aff'd per curiam sub nom. New York v. United States, 397 U.S. 248 (1970) (allegations of antitrust violations by retarding auto emission control innovation); J. Esposiro, supra note 5, at 43.47 (background on suits against Automobile Manufacturers Association).

103. This approach is consistent with the delayed compliance penalty and enforcement provisions of the Act, which permit sources to write off compliance costs against the delayed compliance penalty, or avoid the penalty for three years by using innovative controls. Clean Air Act, $\$ \S 120(d), 113(d)(1), 113(d)(4), 42$ U.S.C.A. $\$ \S 7420(d), 7413(d)(1)$, 7413(d)(4) (West. Supp. 1978). 
The EPA already has some authority that could be used to require private demonstration commitments either in relation to the degree of noncompliance, ${ }^{104}$ or, in the case of some pollutants in some circumstances, in relation to pollutant damage. ${ }^{105}$ The agency should undertake rulemaking under these provisions to induce the appropriate demonstration commitments.

This emission penalty approach would place technology-forcing on a predictable economic basis ${ }^{108}$ and overcome the inherent technologyforcing problems of uncertainty, state law delay, and failure to address interstate air pollution damage. ${ }^{107}$ Additional environmental damage would not be profitable because demonstrations would have to be conducted or compensation for the damage paid to the government. By creating financial incentives to conduct emission-control demonstrations, emission penalties may overcome the profound antipathy that new source standards foster in the private sector toward such research. ${ }^{108}$

Congress's statutory attempt to compel private emission-control innovation was successful. This statutory effort would work more effectively, however, if demonstration requirements were linked to damages in a predictable fashion.

104. The EPA has authority under the delayed compliance penalty provision, nonferrous smelter order provision, and nonattainment area provisions that could be used to require demonstration commitments in proportion to the degree of noncompliance. See p. 1718 supra (discussing delayed compliance penalties); note 47 supra (discussing nonferrous smelter orders); p. 1717 supra (nonattainment area requirements).

105. The EPA's prevention of significant deterioration regulations concerning $\mathrm{NO}_{\mathrm{x}}$, hydrocarbons, photochemical oxidants, and carbon monoxide must provide a "framework: for stimulating improved control technology." Clean Air Act, § 166(c), 42 U.S.C.A. § 7476(c) (West Supp. 1978).

106. The polluter's obligations would be easily determined because the formidable problem of estimating national damages would have been conclusively, if crudely, solved by the EPA. EPA might bypass these formidable estimation problems for the first few years of the program by simply calculating the cost of a reasonable research program for each industry and apportioning the costs on the basis of emissions. In the interim, the agency could develop defensible data and methods to estimate damages, at least for $\mathrm{SO}_{2}$ and $\mathrm{NO}_{\mathrm{x}}$. For toxic pollutants, it might prove impossible to estimate damages in money terms so that using reasonable program costs as the basis for charges may be the only practical approach. See Berger \& Riskin, supra note 100, at 286.87 (setting standards for toxic chemical exposures defies use of traditional cost-benefit analysis techniques). But see American Petroleum Inst. v. Occupational Safety and Health Administration, 581 F.2d 493 (5th Cir. 1978), cert. granted, 47 U.S.L.W. 3541 (U.S. Feb. 2, 1979) (No. 78-911).

107. EPA has not distinguished itself for its speed in setting standards, see note 8 supra (NSPS delays), but once a national standard is set, further delay will not occur in the states.

108. See p. 1728 supra. The emission penalty system would widen the focus of technology-forcing to include not only the package control technologies, such as scrubbers, emphasized by performance standards, but also capital-intensive process changes that have some subsidiary emission-control benefits. Emission penalties, unlike performance standards, provide explicit financial incentives to develop and apply more capital-intensive improvements. 